\title{
Branding Indigeneity: Corporate Patronage of the
} Arts

Branding Indigeneity: patrocinio corporativo de las artes

Patricia A. Banks

\section{(2) OpenEdition \\ Journals}

Electronic version

URL: https://journals.openedition.org/iss/3082

DOI: 10.4000/iss.3082

ISSN: 2306-4161

\section{Publisher}

ICOM - International Council of Museums

\section{Printed version}

Date of publication: 18 December 2021

Number of pages: $56-66$

ISBN: 978-92-9012-446-7

ISSN: 2309-1290

Electronic reference

Patricia A. Banks, "Branding Indigeneity: Corporate Patronage of the Arts", ICOFOM Study Series

[Online], 49-1 | 2021, Online since 18 December 2021, connection on 08 January 2022. URL: http:// journals.openedition.org/iss/3082 ; DOI: https://doi.org/10.4000/iss.3082 


\section{Branding Corporate Patronage of the Arts}

Patricia A. Banks

Mount Holyoke College-South Hadley, MA, USA

\section{A BSTRACT}

Although corporate giving is an important source of support for initiatives related to indigenous cultures, it is less clear how companies gain advantages from patronage. This paper develops the concept of branding indigeneity to describe how companies benefit from philanthropy and sponsorships related to indigenous cultures. More specifically, I argue that corporate patronage related to indigenous cultures is a practice through which companies shape perceptions that they respect and value indigenous peoples. I draw on the case of corporate patronage at the National Museum of the American Indian (NMAI) to empirically illustrate branding indigeneity in the United States.

Key words: diversity, cultural patronage, businesses, branding 


\section{Branding Indigeneity: patrocinio corporativo de las artes}

Aunque las donaciones corporativas son una fuente importante de apoyo para iniciativas relacionadas con las culturas indígenas, no está tan claro cómo las empresas obtienen ventajas del patrocinio. Este artículo desarrolla el concepto de indigeneidad de marca para describir cómo las empresas se benefician de la filantropía y los patrocinios relacionados con las culturas indígenas. Más específicamente, sostengo que el patrocinio empresarial relacionado con las culturas indígenas es una práctica a través de la cual las empresas dan forma a las percepciones de que respetan y valoran a los pueblos indígenas. Me baso en el caso del patrocinio corporativo en el Museo Nacional del Indio Americano (NMAI) para ilustrar empíricamente la indigeneidad de las marcas en los Estados Unidos.

Palabras clave: diversidad, mecenazgo cultural, empresas, marca

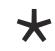

\section{Introduction}

When the National Museum of the American Indian (NMAI) opened in Washington, DC in 2004, among the major donors were companies such as CocaCola, Chase Bank, and Merrill Lynch. In the ensuing years, businesses have continued to support the NMAI. For example, in 2016 Northrop Grumman, an aerospace and defense company, made a $\$ 250,000$ donation for the National Native American Veterans Memorial (NNAVM) on the NMAI grounds. Similarly, in 2018, the railway company BNSF gave a $\$ 500,000$ donation to the memorial project. While we know that corporate support provides needed funds to indigenous cultural institutions and initiatives, it is less clear what corporations stand to gain from their patronage. Building on theory related to branding and communication, this paper argues that patronage related to indigenous cultures provides image-related benefits to companies. More specifically, I argue that corporate philanthropy and sponsorships related to indigenous cultures are a form of what I term branding indigeneity. Or, it is a practice through which corporations shape perceptions that they care about diversity and respect indigenous communities.

To empirically illustrate branding indigeneity via cultural patronage, I examine corporate gifts to the NMAI. I draw on an archive of texts on corporate cultural patronage and other data to demonstrate how giving to the NMAI offers image 
benefits to companies. To provide a foundation for my elaboration of branding indigeneity, I discuss the broader literature on branding and communications. Following this, I present a brief history of the NMAI. Finally, I elaborate the processes through which corporate patronage related to indigenous groups helps businesses to project a positive corporate racial image.

\section{Theory and Literature}

\section{Branding and Communications}

Before delving into how giving to the NMAI is a practice through which corporations communicate that they value diversity and Native Americans, it will be helpful to discuss corporate branding. While a brand is "the sum total of how someone perceives a particular organization... branding is about shaping that perception" (Ashley Friedlein, as cited in Tuten, 2020, p. 340). One of the fundamental processes through which companies shape perceptions about their overall image, as well as specific products and services, is promotional activities. Promotional activities are forms of communication intended to positively engage existing buyers, prospective customers, and other stakeholders with brands-for example, to influence customers viewing brands in a positive way and encouraging them to purchase products.

To communicate with customers and other stakeholders, companies rely on a range of communication channels. In general, these include paid media, i.e. communication channels that companies pay for, such as advertisements placed in magazines or newspapers; owned media, i.e., communication channels that are entirely controlled by companies themselves, such as corporate blogs and newsletters; earned media, which includes third-party forms of communication that are unpaid such as editorial stories in newspapers and magazines along with word-of-mouth communications; and finally, shared media, also called social media, where organizations and individuals communicate with each other through platforms such as Facebook, Twitter, and Instagram (Tuten, 2020). Partnerships, such as collaborations with museums, are a vehicle through which companies directly communicate with stakeholders. Also, messaging related to corporate partnerships is communicated via other channels, such as earned media, owned media, and media channels controlled by museums.

\section{Racial Branding and Branding Diversity}

If branding is the process through which organizations shape perceptions of themselves, then racial branding can be understood as the process through

I. Data for this paper was collected as part of a broader project on corporate patronage of ethnoracial minority culture. In particular, I draw on a database of corporate patronage texts that I developed including press releases, blog posts, social media posts, and other documents publicizing corporate support for cultural initiatives related to racial and ethnic minorities. I also draw on archival documents that I collected from the Smithsonian Archives and photographs that I took during visits to the NMAI. 
which organizations shape racial perceptions about themselves. These racial perceptions surround various aspects of companies-for example, ideas around whether or not a company produces products and services that are appropriate for use by members of particular racial and ethnic groups, whether or not a company treats racial and ethnic minority workers and customers fairly, whether or not a company respects members of specific racial and ethnic groups, and, whether or not a company's products and services are associated with particular racial and ethnic groups and stereotypes about them.

Historically, the racial branding of many businesses in the United States centered on shaping perceptions that products and services were intended to be consumed by whites. For example, prior to the Civil Rights Act of 1964, it was common for establishments in the South, such as restaurants and hotels, to display signs that service was for whites only. Racial branding by mainstream companies in the United States that did include racial and ethnic minorities often focused on establishing and reinforcing brand associations with stereotypes about these groups (Banks, 2020). For example, in the late $19^{\text {th }}$ century it was common for companies to create advertising trading cards with stereotypical images of "the Indian Warrior" (O'Barr, 2013). Similarly, brands have relied on caricatured portrayals of the "American Indian Princess" to link their brands with nature and purity, which are stereotypes associated with Native Americans (O'Barr). ${ }^{2}$

While historically racial branding by businesses often communicated that products and services were for whites and/or linked company images to stereotypes about racial and ethnic minorities, over the course of the latter part of the $20^{\text {th }}$ century and into the $21^{\text {st }}$ century, racial branding has increasingly shifted towards branding diversity (Crockett, 2008; Khamis, 2020). In diversity branding, firms aim to communicate that their products and services are intended to be used by racial and ethnic minorities, that they treat customers and workers across racial and ethnic groups equitably, and that they respect racial and ethnic minorities and care about their well-being.

The shift towards diversity branding is a function of multiple factors such as changing demographics, changing laws, and shifting racial attitudes among whites. For example, growth in the racial and ethnic minority population, due to factors such as increasing immigration from places such as Asia, Latin America, and Africa, means that companies aim to appeal to racial and ethnic minority consumers by communicating that they respect them (Banks, 2020; Dávila, 2001). New anti-discrimination laws also drive companies to communicate that they treat all workers and customers fairly (Edelman, 2016; Skrentny, 2014). In addition, shifting class dynamics, such as the growing black

2. In a similar vein, companies in the United States have a long history of using images of African Americans to associate their brands with racial stereotypes about the group. For example, the use of a black mammy caricature in the Aunt Jemima pancake mix logo links the brand with racial stereotypes about African American women at the service of whites (Banks, 2020, pp. 69-70). 
middle class, compel businesses to convey that their products are intended for use by racial and ethnic minorities and that they respect and care about these groups (Burnett \& Hoffman, 2010; Lamont \& Molnar, 2001). Another important factor shaping racial branding is shifting white racial attitudes. In general, white support for principles of equality, such as integrated schools, interracial marriage, and fair treatment, increased over the course of the $20^{\text {th }}$ century (Bobo, 2001).

\section{Branding Indigeneity}

As we have seen, in some cases, corporate racial branding specifically focuses on indigenous communities, such as Native Americans. I use the term branding indigeneity to refer to a subcategory of diversity branding-instances where companies aim to shape perceptions that they not only respect and celebrate diversity in general but also specifically honor and care about indigenous communities. In this paper, I argue that cultural patronage related to indigenous communities is one form of branding indigeneity. I suggest that this takes place through various mechanisms. These mechanisms are related to the communicative capacities of gifts themselves, the meanings conveyed by written and verbal texts about giving, as well as the symbolic aspects of places related to giving (Banks 2022). I will elaborate each of these mechanisms in more detail and provide examples from corporate patronage at the NMAI.

\section{National Museum of the American Indian: A Brief History}

The NMAI in Washington DC has its foundation in another museum-The Museum of the American Indian (MAI). The MAI was founded by George Gustav Heye, the son of a German immigrant, who was an engineer and also a collector of Native American artifacts. In 1916, Heye founded the MAI, which opened to the public four years later. By the 1980s, there were discussions to move the MAI Collection outside of New York City. One proposal was to merge the MAI with the Smithsonian American Museum of Natural History in Washington, DC. Another plan was for entrepreneur Ross Perot to purchase the collection for $\$ 70$ million and move it to Dallas, Texas. Both proposals fell through. However, on May 8, 1989, an agreement was signed with the Heye Foundation to transfer the Heye Collection to the Smithsonian. A few months later on November 28, 1989, legislation to establish the NMAI was signed. In 1994, the George Gustav Heye Center, which houses a portion of the Heye collection, opened at the Alexander Hamilton U.S. Custom House in New York City. The Cultural Resources Center (CRC), which serves as a storage, conservation, and research facility for the collection, opened in Maryland in 1999. A few months after the CRC opened, the groundbreaking for the NMAI took place. The NMAI finally opened to the public on September 21, 2004.

Corporate philanthropy has played an important role throughout the history of the NMAI. When the museum was in the process of being established, large companies such as Merrill Lynch and Coca-Cola gave donations. Businesses 
have also supported a project of the NMAI-the National Native American Veterans Memorial (NNAVM). In 1994, Congress passed the Native American Veterans Memorial Established Act. As a fundraising document for the memorial notes, "The National Museum of the American Indian will honor Native American servicemen and women in a very visible way: a prominent memorial on the National Mall-a place that draws nearly 24 million visitors annually to Washington, DC" (National Museum of the American Indian [NMAI], n.d., p. 7). Major fundraising for the project, which was expected to cost $\$ 15,000,000$, began in 2013 . Donors who gave $\$ 100,000$ were recognized by having their name included on a donor plaque at the site (NMAI). Companies such as General Motors, Dominion Energy, and Bank of America donated to the memorial, which opened in November 2020.

Corporate funding has played an important role in the establishment and continuing operations of the NMAI. As I will illustrate in detail below, the companies that have supported the NMAI have also benefited from their gifts. More specifically, these gifts function as a form of indigenous branding for these businesses.

\section{Corporate Support of the NMAI}

As consumer culture theory scholar Russell Belk (1977, p. 2) writes, "Perhaps the most general function which gift-giving serves is to act as a form of symbolic communication between the giver and recipient." Gift giving conveys meaning not only when gift givers and receivers are individuals but also when they are organizations, such as corporations donating to cultural institutions. In Belk's elaboration of gift giving as a form of communication, he builds on broader paradigms about communication whereby senders encode messages, deliver them via communication channels, and then receivers decode the messages. However, in the case of gift giving, "the gift is able to act as both message and channel" (Belk, 1977, pp. 2-3). One message that gifts convey is that givers respect and honor receivers (Belk, pp. 2-3). If gift giving remains entirely private, then givers are only communicating with receivers. However, if gift giving is public, for example if it is written about in media channels, then gift givers are communicating with a broader audience.

In the case of corporations giving to the NMAI, gift giving conveys that businesses care about diversity and respect Native Americans. This message is communicated to a large audience. Since the gifts are written about in various media channels, such as press releases and museum publications, the message is disseminated to a wide public. In the case of the fundraising campaign that took place to build the NMAI in the 1990s, one of the museum's newsletters, Campaign News, often ran articles publicizing corporate gifts. For example, various issues of the newsletter had stories with headlines such as "Con Edison Is Donor of NMAI Campaign's First Endowment Gift," "Time Warner Supports Campaign," "Chase Manhattan Bank Gives \$350,000 to Construction Fund," "Proctor \& Gamble Makes \$50,000 Gift," "The Coca-Cola Foundation Makes 
\$500,000 Grant to NMAI," "Merrill Lynch Foundation Continues to Support Through \$250,000 Gift," and "Pfizer Grant Will Benefit Museum Construction Fund." Given that corporate gifts were publicized in the NMAI newsletter, a wide audience was exposed to the messaging encoded in the donations-that the companies value inclusion and care for Native Americans.

On one hand, the NMAI campaign newsletter supported the indigenous branding of corporate donors by simply publicizing gifts. At the same time, the newsletter further reinforced the messaging encoded in the donations via how the gifts were discussed. To explain this mechanism of indigenous branding, it is helpful to refer to cultural anthropologist Grant McCracken's theory on the meaning of consumer goods. In his account, McCracken asserts that meaning is transferred from the culturally constituted world to consumer goods through advertisements. Meaning transfer takes place in advertisements because consumer goods are placed alongside people, places, and objects that have particular meanings in the culturally constituted world. For example, if an advertisement includes an image of a product juxtaposed with an image of a person who is a member of an indigenous group, the product becomes associated with indigenous peoples. Written text plays an important role in the meaning transfer process, as it is the text that offers a guide for interpreting the visual elements of the advertisement. As McCracken (1986) writes,

Text ... makes explicit what is already implicit in the image. Text provides instructions on how the visual part of the advertisement is to be read. The verbal component allows the director to direct the viewer/reader's attention to exactly those meaningful properties that are intended for transfer. (p. 75 )

McCracken's discussion of written text as a prompt directing how advertisements should be interpreted is instructive for further elaborating how corporate gifts to the NMAI help to project an image of companies as valuing diversity and Native Americans. In the case of the NMAI newsletter, discourse about the gifts provided an interpretation of their meaning. Text in the NMAI newsletter informed readers that the gifts had taken place, and reports of verbal discourse about the gifts in the newsletter offered an interpretation of the gifts. One such interpretation was that the gifts were a reflection of the "generosity" of the corporations. For example, in a story about Merrill Lynch's donation, the NMAI's then-director is quoted as saying, "I am most appreciative of the ongoing generosity of Merrill Lynch, which is clearly demonstrated by this recent grant" (W. Richard West as cited in Merrill Lynch, 1993, p. 3).

Discourse about the donations in the NMAI newsletter also directly reinforced messaging encoded in the gifts that the companies had a deep commitment to diversity and Native Americans. For example, a report about a gift from AT\&T 
to support the opening exhibition at the Heye Center includes a quotation from an AT\&T Foundation executive who explains that "[t]his exhibition exemplifies AT\&T's commitment to support the works of innovative contemporary artists of diverse cultures who challenge our perceptions and understanding of the world we live in" (Foundations Support, 1994, p. 9). A story about a $\$ 100,000$ donation from Anheuser-Busch frames the NMAI donation as part of a broader pattern of championing diversity at the company, noting that the business "supports the work of the American Indian College Fund" and "has been a corporate patron of the United Negro College Fund and the National Hispanic Scholarship Fund for many years" (Anheuser-Busch, 1996, p. 3). A story about Coca-Cola's gift also couches the NMAI donation within a broader history of diversity outreach at the company. It notes that the company foundation

supports an array of programs that serve and provide scholarships for American Indian students nationwide, including the American Indian College Fund; the First Nations Development Institute; the Rogers College Foundation in Claremore, Oklahoma; Oklahoma City University; Futures for Children in Albuquerque, New Mexico; and the Santa Fe Opera. (Coca-Cola, 1995, p. 7)

99

Corporate gifts to support the veterans' memorial also frame the donations as an expression of a commitment to diversity and Native Americans. For example, a press release by BNSF Railways about the company's memorial donation not only notes the $\$ 500,000$ gift, but also contextualizes it as part of the company's broader outreach to Native Americans. In particular, the press release discusses the company's "Tribal Relations Team" stating that,

The BNSF Tribal Relations team is the first in the industry and was established to build and strengthen ties with the many diverse tribal nations within the BNSF railroad network. The team also works to foster within BNSF a greater cultural understanding of these tribal nations, their rights and governance and cultural issues. In reaching out to the 86 tribal governments and leaders that BNSF touches, the Tribal Relations team has established a high standard in the industry for the future of corporate-to-tribal communication and relationship building. (BNSF Railway, 2018)

In a similar fashion, a press release put out by the Smithsonian about aerospace and defense company Northrop Grumman's \$250,000 donation for the memorial couches the gift as an articulation of the company's deep commitment to 
Native Americans. For example, a passage in the press release provides specific examples of the company's programs to support Native Americans noting that,

Since 1970, Northrop Grumman has actively worked to partner with Native and tribally owned businesses through supplier partnerships and operations in Indian Country. The company has also been a longtime supporter of Native Americans through scholarship and mentor programs, employee diversity recruitment and retention, Native American Employee Resource Groups, and participation in the Indian Incentive Program. (Maxwell, 2016, p. 3)

A third factor to consider in how corporate donations to the NMAI serve as a tool for indigenous branding relates to the museum building and grounds. When a business gives a large donation to a museum, it is common for the company name to be placed on and/or in the museum. This naming dynamic is key to corporate branding. To elaborate this mechanism further, it is helpful to engage the scholarship on spaces as symbols (Monnet, 2011). In his writing about place, Thomas F. Gieryn (2000) asserts that places have the following characteristics-a geographic location, a material form, and an investment with meaning and value. Applying this perspective to museums, museums are not only material forms located in particular geographical spaces, they are also entities with particular meanings. When corporate names and logos are placed on and in museum buildings, the museums stand as places which convey the idea that these companies value not only the art and artifacts displayed and exhibited in the museum but also the people who produced and consumed those objects. Moreover, museums function as places promoting the message that companies care about the people whose culture and history are associated with the architectural design of the building and surrounding landscape.

The NMAI not only houses material culture and other objects produced and consumed by Native peoples in the Western Hemisphere but also, in the architecture of the building itself along with the surrounding landscape, articulates the cultural values, beliefs, and histories of these groups. For example, the building "evoke[s] a wind-sculpted rock formation" and the landscape "recall[s] the natural environment that existed prior to European contact" (NMAI, 2020). The grounds include elements such as traditional croplands, Grandfather Rocks, and Cardinal Direction Markers. Inside the museum, on one of the buff-colored stone walls, is a set of plaques listing names of donors. Among the dozens of names are corporations such as $3 \mathrm{M}$ and $3 \mathrm{M}$ Foundation; Accenture; The Coca-Cola Foundation; JP Morgan Chase \& Co.; Merrill Lynch \& Co. Foundation, Inc.; American Express; Bank of America; Con Edison; Eastman Kodak Company; Goldman Sachs; Mars Chocolate North America; MetLife Foundation; Mobil Corporation; and Starbucks Coffee Company. With the 
names of these corporations written on the wall of NMAI, the museum conveys the idea that these companies value diversity and care about Native Americans.

To summarize, corporate giving to the NMAI is a form of indigenous branding whereby companies project an image of caring about diversity and Native Americans. This takes place through various mechanisms including gift giving itself serving as a medium communicating this message; media about gifts disseminating this message along with reinforcing it with textual discourse; and the museum building standing as a symbolic place that conveys this message.

\section{References}

Anheuser-Busch. (1996). Anheuser-Busch Contributes \$100,000. Campaign News, Spring, 3.

Banks, P. A. B. (2020). Race, ethnicity, and consumption: A sociological view. Routledge.

Banks, P. A. B. (2022). Black culture, Inc: How ethnic community support pays for corporate America. Stanford University Press.

BNSF Railway. (2018, December 1). BNSF railway foundation supports national Native American veterans memorial. BNSF News. https://perma. cc/6GB7-QW4X

Belk, R. W. (1977). Gift-giving behavior [Faculty working papers part A]. College of Commerce and Business Administration, University of Illinois at Urbana-Champaign.

Bobo, L. D. (2001). Racial attitudes and relations at the close of the twentieth century. In N. J. Smelser, J. Neil, W. J. Wilson, \& F. Mitchell (Eds.), America becoming: Racial trends and their consequences (Vol. 1), (pp. 264301). National Academy Press.

Burnett, L. E., \& Hoffman, A. (2010). Black is the new green: Marketing to affluent African Americans. Palgrave Macmillan.

Coca-Cola. (1995). The Coca-Cola foundation makes $\$ 500,000$ grant to NMAI. Campaign News, 4(1), 7.

Crockett, D. (2008). Marketing blackness: How advertisers use race to sell products. Journal of Consumer Culture, 8(2), 245-68. https://doi. org/10.1177/1469540508090088

Dávila, A. (2001). Latinos, inc.: The marketing and making of a people. University of California Press.

Edelman, L. (2016). Working law: Courts, corporations, and symbolic civil rights. University of Chicago Press. 
Foundations Support. (1994). Foundations Support Museum Opening. Campaign News, Fall, 9.

Gieryn, T. F. (2000). A space for place in sociology. Annual Review of Sociology, 26, 463-496. https://doi.org/10.1146/annurev.soc.26.1.463

Khamis, S. (2020). Branding diversity: New advertising and cultural strategies. Routledge.

Lamont, M., \& Molnár, V. (2001). How blacks use consumption to shape their collective identity: Evidence from African-American marketing specialists. Journal of Consumer Culture, 1(1), 31-45. https://doi. org/10.1177/146954050100100103

Maxwell, E. (2016, November 14). National Museum of the American Indian receives major gift from Northrop Grumman Corporation to help build a National Native American Veterans Memorial. Smithsonian Institution News, 1-4. https://perma.cc/P3Q9-FE32

McCracken, G. (1986). Culture and consumption: A theoretical account of the structure and movement of the cultural meaning of consumer goods. Journal of Consumer Research, 13(1), 71-84. https://doi.org/10.1086/209048

Merrill Lynch. (1993, Fall-Winter). Merrill Lynch Foundation continues to support through $\$ 250,000$ gift. Campaign News, 3 .

Monnet, J. (2011). The symbolism of place: A geography of relationships between space, power and identity (A. Verdier, Trans.). Cybergeo: European Journal of Geography. https://doi.org/10.4000/cybergeo.24747

National Museum of the American Indian. (2020). Architecture and landscape: The architectural design process. Smithsonian Institution. https://perma. cc/V7KK-HMVV

National Museum of the American Indian. (n.d.). National Native American Veterans Memorial: Honoring Native American military service [Fundraising pamphlet]. Smithsonian Institution. https://perma.cc/8Y2X-4P3R

O'Barr, W. M. (2013). Images of Native Americans in advertising. Advertising \& Society Review, 14(1), 1-51.

Skrentny, J. D. (2014). After civil rights: Racial realism in the new American workplace. Princeton University Press.

Tuten, T. L. (2020). Principles of marketing for a digital age. Sage Publication. 